\title{
Rechtszekerheid als ratio van subjectief verjaringsrecht
}

\author{
Mr. D.L. Barbiers*
}

\section{Inleiding}

Er bestaat onzekerheid over de ratio van het subjectieve verjaringsrecht. Smeehuijzen heeft in zijn invloedrijke dissertatie betoogd dat de korte termijn van art. 3:310 lid 1 BW een gestandaardiseerde vorm van rechtsverwerking is (de rechtsverwerkingsgedachte), maar signaleert tegelijkertijd dat de rechtspraak van de Hoge Raad niet altijd (volledig) lijkt te kunnen worden verklaard door die gedachte. ${ }^{1}$ Illustratief voor het feit dat het subjectieve verjaringsrecht nog niet in rustig vaarwater lijkt te zijn gekomen, is het recente arrest Mispelhoef/Staat, waarin de Hoge Raad over het startmoment anders oordeelde dan A-G Keus en het hof in het bestreden arrest. ${ }^{2}$ Nog recenter heeft de Hoge Raad de toepassing van de korte termijn van art. 3:310 lid $1 \mathrm{BW}$ (in een voetnoot) uitdrukkelijk vergeleken met zijn rechtspraak over de klachtplicht van art. 6:89 BW. ${ }^{3}$ Hij heeft echter niet expliciet overwogen dat de korte verjaringstermijn van art. 3:310 lid $1 \mathrm{BW}$ een vorm van rechtsverwerking is.

Met Smeehuijzen meen ik dat een helder begrip van de ratio van het subjectieve verjaringsrecht een belangrijk perspectief kan zijn bij actuele vragen over het startmoment van de korte verjaringstermijn, ${ }^{4}$ zoals de vraag hoe zeker een schuldeiser moet zijn over het ontstaan van zijn vordering voordat deze

* Mr. D.L. Barbiers is promovendus en docent burgerlijk recht aan de Radboud Universiteit Nijmegen. Hij is verbonden aan het Onderzoekscentrum Onderneming \& Recht.

Dit artikel is afgerond op 29 september 2020. Met ontwikkelingen na deze datum is incidenteel rekening gehouden.

1. Zie J.L. Smeehuijzen, Ongelukkig HR 6 april 2012 (verjaring bij hoofdelijkheid) illustreert behoefte aan duidelijk normatief perspectief op verjaringsrecht, VR 2012/130, par. 1.2 en 3.1 (met verwijzing naar o.a. HR 9 april 2010, ECLI:NL:HR:2010:BL1118, NJ 2010/215, r.o. 4.1.5); J.L. Smeehuijzen, De bevrijdende verjaring (diss. Amsterdam VU; Recht en Praktijk, deel 162), Deventer: Kluwer 2008, par. 9.2, 11.1.2, 11.3.2, 21.2.1 en 27. Zie ook de conclusie van A-G Valk bij HR 9 oktober 2020, ECLI:NL:HR:2020:1603, punt 3.9; J.E. Jansen, Geen bevrijdende verjaring zonder rechtsverwerking, RMThemis 2009, afl. 5, p. 215-219.

2. HR 31 maart 2017, ECLI:NL:HR:2017:552, NJ 2017/165. Zie ook HR 10 januari 2020, ECLI:NL:HR:2020:20, NJ 2020/122 m.nt. T.F.E. Tjong Tjin Tai, r.o. 3.1-3.2.3 en 3.4.1-3.4.2 (een gedeeltelijk contrair arrest, vgl. punt 3.32 van de conclusie van A-G Hartlief), en punt 3 van de noot van T.F.E. Tjong Tjin Tai.

3. Zie HR 9 oktober 2020, ECLI:NL:HR:2020:1603, r.o. 3.3.3, voetnoot 6 . Art. 6:89 BW is naar het oordeel van de Hoge Raad een vorm van rechtsverwerking, zie HR 12 december 2014, ECLI:NL:HR:2014:3593, NJ 2017/163 m.nt. W.D.H. Asser, r.o. 5.6.3.

4. Smeehuijzen 2012, par. 3.2. termijn begint te lopen. ${ }^{5}$ Een onderzoek naar de ratio van het subjectieve verjaringsrecht kan dus praktische betekenis hebben voor concrete zaken waarin het subjectieve verjaringsrecht wordt toegepast. Dit heeft mij aanleiding gegeven om de ratio van de korte termijn van art. 3:310 lid 1 BW nader te onderzoeken. ${ }^{6}$

Volgens de rechtsverwerkingsgedachte hangt de ratio (of het doel) van de korte termijn van art. 3:310 lid $1 \mathrm{BW}$ samen met twee gevolgen van verwijtbaar stilzitten: (1) de bewijspositie van de schuldenaar verslechtert en (2) de schuldenaar wordt met psychologische onzekerheid en nadelige economische gevolgen geconfronteerd. In de rechtsverwerkingsgedachte wordt vervolgens het startmoment van de korte termijn van art. 3:310 lid $1 \mathrm{BW}$ gekoppeld aan het moment waarop redelijkerwijs verwacht mag worden dat een schuldeiser zijn vordering kan instellen. Doet hij dat niet, dan rechtvaardigt dit 'stilzitten' dat zijn vordering is verjaard. Dat zou, gelet ook op de 'hanteerbaarheid' van de regel, moeten resulteren in het volgende startmoment: 'bekendheid met alle feiten waarop de vordering berust is vereist, (...)', aldus Smeehuijzen. ${ }^{7} \mathrm{De}$ rechtsverwerkingsgedachte veronderstelt dat sprake is van verwijtbaar stilzitten als de schuldeiser ondanks die kennis geen juridische stappen zet. Daarmee zou de korte termijn van art. 3:310 lid $1 \mathrm{BW}$ lijken op rechtsverwerking.

In dit artikel betoog ik dat rechtsverwerking en de korte termijn van art. 3:310 lid $1 \mathrm{BW}$ weliswaar zien op eenzelfde soort belangenconflict tussen schuldeiser en schuldenaar (par. 2), maar dat zij niet geheel dezelfde ratio hebben

5. Deze vraag deed zich recent nog voor in HR 31 maart 2017, ECLI:NL:HR:2017:552, NJ 2017/165, r.o. 3.3.2, en leidde tot een contrair arrest. Zie nader par. 5. Vgl. voor andere vragen, bijv. E.F. Verheul, Voortdurende gedragingen en de subjectieve verjaringstermijn van art. 3:310 lid 1 BW, NTBR 2020/17, par. 3, over voortdurende gedragingen, en in het kader van toekomstige schade, M.R. Hebly, Verjaring van schadevergoedingsvorderingen bij toekomstige schade: kan de korte verjaringstermijn lopen voordat schade is geleden?, in: D.F.H. Stein, V. Tweehuysen \& S.E. Bartels (red.), Verjaring (Onderneming en recht, deel 120), Deventer: Wolters Kluwer 2020, par. 5.3.3 en 5.4; en E.F. Verheul, Verjaring en het ontstaan van schade, NTBR 2020/32, par. 4.

6. Smeehuijzen identificeert dit zelf als het 'spannendste deel van het boek [zijn proefschrift; DB]', zie J.L. Smeehuijzen, De bevrijdende verjaring herzien, AA 2020, afl. 5, p. 511. Vgl. verder D.L. Barbiers, Verwerking van het enquêterecht, MvO 2016, afl. 10-11, p. 276-277.

7. Zie Smeehuijzen 2008, par. 16.3.3.1 en 16.4. 


\section{Maandblad}

(par. 3-6). ${ }^{8}$ In mijn opvatting is art. 3:310 lid $1 \mathrm{BW}$ dus niet geheel hetzelfde als een vorm van rechtsverwerking (in conceptuele zin). Art. 3:310 lid $1 \mathrm{BW}$ dient de rechtszekerheid in die zin dat het de schuldenaar en eventuele derden in staat stelt om zonder rechterlijke tussenkomst in te schatten vanaf welk moment een schuldenaar niet meer gedwongen kan worden om een schadevergoedingsverplichting na te komen. ${ }^{9}$ Ook als de schuldenaar onbekend is met de schade en hij daarom het startmoment zelf niet goed kan inschatten, kan de korte termijn de rechtszekerheid van de schuldenaar bevorderen. Het is immers denkbaar dat schuldeisers door de korte verjaringstermijn worden gestimuleerd om hun mogelijke vordering relatief snel kenbaar te maken aan de schuldenaar. ${ }^{10}$ De schuldenaar kan dan met een mogelijke claim rekening houden bij het bewaren van bewijsmateriaal of andere (economische) beslissingen.

Zekerheidshalve merk ik op dat de vraag of het subjectieve verjaringsrecht daadwerkelijk altijd tot meer rechtszekerheid - in de hiervoor bedoelde zin - voor de schuldenaar leidt, empirisch van aard is. Op die vraag geef ik in dit artikel geen definitief antwoord. ${ }^{11}$ Met een analyse van de wet, wetsgeschiedenis en rechtspraak onderzoek ik de normatieve achtergrond die het subjectieve verjaringsrecht volgens de wetgever en de Hoge Raad heeft. In dat kader onderzoek ik ook de bedoeling van de wetgever bij het aanvangsmoment van de subjectieve verjaringstermijn en jurisprudentie van de Hoge Raad over de rol van de billijkheid op dit punt. Verder kom ik tot de conclusie dat rechtsverwerking niet een duidelijke termijn kent en daarom veel minder goed kan leiden tot rechtszekerheid van de

8. Vgl. met de nodige voorzichtigheid R.P.J.L. Tjittes \& H. Boom, Rechtsverwerking en klachtplichten (Mon. BW nr. A6b), Deventer: Wolters Kluwer 2020, par. 10 en verder Barbiers 2016, p. 276-277. Zie over de ratio van bevrijdende verjaring in het algemeen Asser/Sieburgh 6-II 2017/381-386.

9. Vgl. voor rechtszekerheid als ratio van verjaringsrecht Smeehuijzen 2020, p. 508-509 (ook Smeehuijzen identificeert aspecten van de rechtszekerheid die het verjaringsrecht dient); Smeehuijzen 2012, par. 1.1; Smeehuijzen 2008, par. 8.4, 9.2; M.W.E. Koopmann, Bevrijdende verjaring (Mon. BW nr. B14), Deventer: Kluwer 2010/6.1; N.E. Groeneveld-Tijssens \& A.C. van Schaick, Een tweeluik over bevrijdende verjaring en rechtsdwaling. Deel I: de invloed van het EVRM, NTBR 2017/11, p. 84 (hierna: Groeneveld-Tijssens \& Van Schaick 2017a); T. Hartlief, Verjaring, rechtszekerheid en billijkheid, NTBR 2001, afl. 2, p. 63; noot van T.F.E. Tjong Tjin Tai bij HR 14 november 2014, ECLI:NL:HR:2014:3240, NJ 2015/207, onder 2; noot van H.J. Snijders bij HR 20 april 2001, ECLI:NL:HR:2001:AB1208, NJ 2002/384, onder 8; noot van A.R. Bloembergen bij HR 25 juni 1999, ECLI:NL:HR:1999:ZC2934, NJ 2000/16, onder 4; noot van A.R. Bloembergen bij HR 28 april 2000, ECLI:NL:HR:2000:AA5634, NJ 2000/431, onder 5; Tjittes \& Boom 2020, par. 10; M. Bredenoord-Spoek, Aansprakelijkheid van de Staat voor 'zuiveringsacties' op Zuid-Sulawesi en doorwerking van de redelijkheid en billijkheid in ons verjaringsrecht, MvV 2020, afl. 2, p. 75, 79 (mede in het licht van de billijkheid). Zie over rechtszekerheid in de zin van voorspelbaar recht (afgezet tegen de billijkheid) H.Th. Bouma \& M.J. Kroeze, Verjaring tussen rechtszekerheid en billijkheid, in: A.G. Castermans e.a. (red.), De landsadvocaat, voor deze: opstellen voor J.L. de Wijkerslooth, Den Haag: Boom Juridische uitgevers 1999, p. 31-33, 37-38 en 40-41.

10. Zie ook Groeneveld-Tijssens \& Van Schaick 2017a, p. 84.

11. Wel spreek ik af en toe over verwachtingen en waarschijnlijkheden. schuldenaar in de hiervoor bedoelde zin. ${ }^{12}$ In dit artikel laat ik Europeesrechtelijke en mensenrechtelijke aspecten, zoals het effectiviteitsbeginsel en het EVRM, buiten beschouwing. ${ }^{13}$

\section{Eén belangenconflict, twee oplossingen}

Achter de korte verjaringstermijn van art. 3:310 lid $1 \mathrm{BW}$ en rechtsverwerking gaat eenzelfde soort belangenconflict schuil. Enerzijds heeft de schuldeiser een belang bij het kunnen afdwingen van zijn recht, mogelijk ook na verloop van tijd; anderzijds kan een schuldenaar (en eventuele derden) in bewijsrechtelijk en/of economisch opzicht worden benadeeld als de schuldeiser na een bepaald tijdsverloop toch besluit een vordering in te stellen. Voor dit belangenconflict moet het recht een oplossing bieden dat een evenwicht vormt, althans dat lijkt een breedgedragen rechtsgevoel. ${ }^{14}$ Het recht kan die oplossing met behulp van grofweg twee mechanismen geven:

1. Het recht geeft met een vaste termijn een regel tot welke dag dit belangenconflict in het voordeel van de schuldeiser uitvalt.

2. De rechter beslist in een concreet geval welk belang zwaarder weegt aan de hand van de omstandigheden van het geval.

Art. 3:310 lid $1 \mathrm{BW}$ is een wettelijke implementatie van mechanisme 1. Mechanisme 2 is bijvoorbeeld terug te vinden bij de discretionaire ruimte die de rechter heeft bij de toe- of afwijzing van een enquêteverzoek (art. 2:345 jo. art. 2:350 BW) en bij rechtsverwerking. ${ }^{15}$

12. Dit neemt niet weg dat er zich gevallen kunnen voordoen waarin een schuldeiser geadviseerd kan worden over rechtsverwerking, en vervolgens zonder procedure tot de conclusie komt dat hij zijn vordering niet meer kan afdwingen. Of dit inderdaad vaak voorkomt, is een empirische vraag die zich niet goed leent voor beantwoording in dit artikel.

13. Zie hierover D.F.H. Stein, Verjaring van rechtsvorderingen van particulieren wegens schending van Unierecht, in: D.F.H. Stein, V. Tweehuysen \& S.E. Bartels, Verjaring (Onderneming en Recht, deel 120), Deventer: Wolters Kluwer 2020, par. 24.2; Groeneveld-Tijssens \& Van Schaick 2017a.

14. Ook de minister heeft benadrukt dat dit (of in ieder geval een soortgelijk) belangenconflict achter het verjaringsrecht schuilgaat. Zie Kamerstukken II 1999/2000, 26824, nr. 3, p. 2 (MvT). Vgl. ook R.P.J.L. Tjittes, Bevrijdende verjaring: van rechtszekerheid naar billijkheid, WPNR 2002, afl. 6472, p. 53; de noot van C.E. du Perron bij HR 3 december 2010, ECLI:NL:HR:2010:BN6241, NJ 2012/196, onder 'Inleiding'.

15. HR 30 maart 2007, ECLI:NL:HR:2007:AZ8210, NJ 2007/293 m.nt. J.M.M. Maeijer, r.o. 4.4; HR 18 november 2005, ECLI:NL:HR: 2005:AU2465, NJ 2006/173 m.nt. J.M.M. Maeijer, r.o. 4.4.2; HR 20 november 1996, ECLI:NL:HR:1996:AD2646, NJ 1997/188 m.nt. J.M.M. Maeijer, r.o. 3.3.1-3.3.3; HR 11 november 2016, ECLI:NL:HR: 2016:2574, NJ 2017/75 m.nt. P. van Schilfgaarde, r.o. 4.2. Rechtsverwerking verschilt wel op fundamenteel niveau van de belangenafweging bij de toe- of afwijzing van een enquêteverzoek. Waar de belangenafweging bij de toe- of afwijzing van een enquêteverzoek gebaseerd is op art. 2:345 BW (de Ondernemingskamer 'kan' een enquêteverzoek toewijzen) en art. 2:350 BW, vormen de redelijkheid en billijkheid de grondslag van rechtsverwerking (art. 6:2 lid 2 jo. art. 6:248 lid 2 BW). Een zeker tijdsverloop kan bij beide leerstukken een rol spelen. Zie HR 11 november 2016, ECLI:NL:HR:2016:2574, NJ 2017/75 m.nt. P. van Schilfgaarde, r.o. 5.2.2. Zie over de verhouding tussen beide leerstukken Barbiers 2016, p. 281-283. 
Het type evenwicht (mechanisme 1 of 2) wordt gekozen door de wetgever en/of ontwikkeld in de jurisprudentie op basis van normatieve overwegingen. Zo heeft het verjaringsrecht als voordeel dat het de schuldenaar in voorkomende gevallen zekerheid kan bieden over de vraag tot welk moment een schuldeiser zijn vordering kan afdwingen, en dat het schuldeisers kan stimuleren om hun vordering relatief snel mee te delen aan de schuldenaar (beide aspecten dragen bij aan de rechtszekerheid van de schuldenaar). Met een duidelijke en voorspelbare verjaringsregel kan overigens ook de schuldeiser beter inschatten of en wanneer zijn vordering is verjaard. ${ }^{16}$ Treffend vind ik de opmerking van Bloembergen over de rol van de rechtszekerheid bij art. 3:310 lid $1 \mathrm{BW}:{ }^{17}$

' $\mathrm{Nu}$ is een belangrijk element van de rechtszekerheid de voorspelbaarheid en hanteerbaarheid van het recht die kan worden bereikt door hard and fast rules. Het behoeft geen toelichting dat een jongleren met omstandigheden en gezichtspunten wel iets anders is dan het toepassen van dit soort regels.'

Vergeleken met een belangenafweging aan de hand van de omstandigheden van het geval (mechanisme 2) zijn dit inderdaad onderscheidende eigenschappen van het verjaringsrecht, omdat bij een belangenafweging vaak pas achteraf in een procedure duidelijk wordt welk belang zwaarder weegt. ${ }^{18}$ Een belangenafweging lijkt minder goed voorspelbaar (en lijkt daarom niet zozeer ex ante-effecten te kunnen hebben), maar biedt mogelijk wel meer flexibiliteit. Deze verschillende systematische eigenschappen hebben dus eigen voordelen, wat een reden kan zijn om een van deze leerstukken (of beide) te introduceren in het recht.

Niet alleen voor het type evenwicht, maar ook binnen mechanisme 1 en mechanisme 2 vallen normatieve keuzes te maken. Zo kunnen de belangen van de schuldeiser relatief worden bevoordeeld door in plaats van een objectief startmoment een subjectief startmoment te kiezen voor mechanisme 1, maar worden deze relatief benadeeld door in plaats van een lange verjaringstermijn een korte termijn te kiezen. De belangenafweging bij mechanisme 2 kan door wetgeving of jurisprudentie in het voordeel van een bepaalde partij worden toegepast. Denk aan de zware toepassingsvoorwaarden voor rechtsverwerking met een focus op de gedragingen van de schuldeiser (zie nader par. 6). Ook de belangenafweging die dient plaats te vinden bij de toe- of afwijzing van een enquêteverzoek kent een structurele eigenschap die een bepaalde partij

16. Vgl. de noot van A.R. Bloembergen bij HR 28 april 2000, ECLI:NL:HR: 2000:AA5634, NJ 2000/431, onder 5; Kamerstukken I 2002/03, 26824, nr. 105, p. 13-14 (NMvA); Groeneveld-Tijssens \& Van Schaick 2017a, p. 84 .

17. Noot van A.R. Bloembergen bij HR 28 april 2000, ECLI:NL:HR: 2000:AA5634, NJ 2000/431, onder 5.

18. Vgl. over het verschil tussen de klachtplicht en verjaring de conclusie van A-G Wissink bij HR 8 februari 2013, ECLI:NL:HR:2013:BY4600, NJ 2014/497 m.nt. Jac. Hijma, punt. 2.7.3 en 3.7.3. lijkt te bevoordelen. De Hoge Raad heeft bepaald dat het enquêterecht vooral het belang van de rechtspersoon dient. ${ }^{19}$

Kortom: voor de ratio en daarmee de interpretatie van het subjectieve verjaringsrecht biedt het feit dat het een evenwicht vormt tussen belangen van de schuldeiser enerzijds en die van de schuldenaar en eventuele derden anderzijds geen richting. Het precieze evenwicht voor dit belangenconflict wordt op basis van normatieve overwegingen vastgesteld door de wetgever en in de jurisprudentie. Of de keuze voor de korte termijn van art. 3:310 lid $1 \mathrm{BW}$ inderdaad is ingegeven door de rechtszekerheid moet worden nagegaan op basis van de wet, wetsgeschiedenis en rechtspraak. Maar die ratio sluit niet uit dat de wetgever voor een bepaald startmoment kiest dat vanuit rechtszekerheidsperspectief minder wenselijk is dan andere denkbare startmomenten, of dat ook een andere overweging dan de rechtszekerheid relevant kan zijn geweest voor de keuze voor een bepaald startmoment. Als zich een interpretatievraagstuk bij een specifiek aspect van art. 3:310 lid $1 \mathrm{BW}$ voordoet, moet dus ook worden nagegaan wat over dat specifieke aspect valt af te leiden uit de wet, wetsgeschiedenis en rechtspraak. Het antwoord op deze vragen zal ik hierna onderzoeken.

\section{De subjectieve verjaringstermijn dient (ook) de rechtszekerheid}

\subsection{Subjectief verjaringsrecht als onderdeel van bevrijdende verjaring in brede zin}

De korte verjaringstermijn van art. 3:310 lid 1 BW kan rechtszekerheid bieden, omdat het schuldenaren in voorkomende gevallen in staat kan stellen om na te gaan wanneer een schadevergoedingsvordering niet meer kan worden afgedwongen. In zoverre komt het subjectieve verjaringsrecht overeen met het objectieve verjaringsrecht. Waar het objectieve verjaringsrecht voor schadevergoedingsvorderingen aansluit bij de schadeveroorzakende gebeurtenis, geldt voor het subjectieve verjaringsrecht iets anders. Het startpunt van de korte verjaringstermijn van art. 3:310 lid $1 \mathrm{BW}$ wordt - zoals hierna wordt toegelicht - bepaald door de vraag op welk moment de schuldeiser daadwerkelijk in staat is zijn vordering in te stellen.

Er zijn verschillende situaties denkbaar waarin de schuldenaar of eventuele derden (na overleg met de schuldenaar) kunnen leunen op de rechtszekerheid die het subjectieve verjaringsrecht biedt: ${ }^{20}$

- Een schuldenaar kan inschatten tot welk moment hij bewijsmateriaal moet bewaren en hoe groot de kosten zijn die daarmee gepaard gaan. Denk aan het afsluiten van contracten voor het bewaren van informatie in datacentra of archieven.

19. HR 6 juli 2018, ECLI:NL:HR:2018:1104, NJ 2019/394 m.nt. G. van Solinge, r.o. 3.4.6; HR 30 maart 2007, ECLI:NL:HR:2007:AZ8210, NJ 2007/293 m.nt. J.M.M. Maeijer, r.o. 4.4 .

20. Deze voorbeelden zijn vooral geïnspireerd op Smeehuijzen 2008, par. 8.2 en 8.5 
- Bij (sommige) massaschadezaken zou een schuldenaar een inschatting kunnen maken van wanneer vorderingen van schuldeisers verjaard zullen zijn, zodat hij vanaf dat moment mogelijk eerder geneigd zal zijn om te schikken met een of meerdere schuldeisers die tijdig hebben gestuit (anders kan hij de totale exposure niet goed inschatten, gezien de mogelijke precedentwerking van een dergelijke schikking). ${ }^{21}$

- Het subjectieve verjaringsrecht kan mogelijk invloed hebben op het antwoord op de vraag tot wanneer boekhoudkundig een voorziening moet worden getroffen. Meer in het algemeen biedt het een schuldenaar of eventuele derden die voor hem garant staan (na overleg) duidelijkheid over de vraag wanneer een vordering niet langer kan worden afgedwongen. Denk in dit verband ook aan de positie van aansprakelijkheidsverzekeraars.

- Kredietverstrekkers kunnen bij hun onderzoek naar de financiële positie van de partij die om financiering vraagt in overleg met die partij een inschatting maken van de (aankomende) verjaring van claims die zijn gericht tegen de partij die financiering zoekt.

- Bij aandelentransacties kan het subjectieve verjaringsrecht helpen om in te schatten of nog niet ingestelde claims tegen de vennootschap waarin (meer) aandelen zullen worden verkregen, zijn of snel zullen zijn verjaard. Dat kan invloed hebben op de prijs van die aandelen of andere voorwaarden van de transactie.

Weliswaar zal de korte verjaringstermijn van art. 3:310 lid 1 BW voor de schuldenaar minder duidelijkheid bieden dan het objectieve verjaringsrecht, omdat 'de schadeveroorzakende gebeurtenis' een objectiever startmoment is. Maar het valt te verwachten dat een schuldenaar en eventuele derden (na overleg met de schuldenaar) op basis van het subjectieve verjaringsrecht in voorkomende gevallen wel tot op zekere hoogte kunnen inschatten wanneer een schuldeiser bekend is met zijn schade en de daarvoor aansprakelijke persoon, ${ }^{22}$ en in het verlengde daarvan wanneer de schuldeiser daadwerkelijk in staat is om een vordering in te stellen. ${ }^{23}$ Dat zou moeilijker zijn als ook vereist is dat de schuldeiser absolute zekerheid heeft over zijn claim en/of dat hij wetenschap heeft van de juridische beoordeling van feiten over de schade of aansprakelijke persoon, maar die eisen stelt de Hoge Raad nadrukkelijk niet

21. Vgl. R.M. Hermans, De oorzaken van het niet tot stand komen van collectieve schikkingen in massaschadezaken, in: M. Holtzer e.a. (red.), Geschriften vanwege de Vereniging Corporate Litigation 2014-2015 (Serie vanwege het Van der Heijden Instituut, deel 128), Deventer: Wolters Kluwer 2015, par. III.14.4.2.

22. In die zin zou ik willen nuanceren dat subjectief verjaringsrecht geen zekerheid voor schuldenaren oplevert. Zie Groeneveld-Tijssens \& Van Schaick 2017 a, p. 78.

23. Omdat een beroep op het subjectieve verjaringsrecht niet ambtshalve wordt getoetst, ontstaat pas duidelijkheid bij een derde als hij weet dat de schuldenaar daarop wel of niet een beroep zal doen. Dat kan hij met de derde bespreken. Als een schuldenaar niet van plan is een beroep op verjaring te doen, is mijn verwachting dat hij doorgaans van plan zal zijn de vordering te voldoen. In dat geval bestaat om die reden al geen rechtsonzekerheid bij de schuldenaar of derde (na overleg met de schuldenaar). (zie nader par. 4). Een voorbeeld waarin de schuldenaar het startmoment van de subjectieve termijn tot op zekere hoogte zou kunnen inschatten, is het geval van misleiding door een beursgenoteerde instelling waardoor (professionele) beleggers schade hebben geleden. Ook voor de schuldenaar is dan duidelijk wanneer de korte verjaringstermijn begint te lopen, als daarvoor als startmoment geldt het moment waarop die misleiding en de gevolgen voor de desbetreffende beleggers - in wezen de feitelijke grondslag van de vordering van de desbetreffende beleggers - landelijk (door de pers) bekend worden (gemaakt). ${ }^{24}$ Als de schuldenaar niet op de hoogte is van door hem aangerichte schade, laat staan van kennis van de schuldeiser over die schade, komt subjectief verjaringsrecht de rechtszekerheid van de schuldenaar op een andere manier tegemoet. Schuldeisers worden gestimuleerd hun vordering aan de schuldenaar mee te delen binnen vijf jaren nadat zij daadwerkelijk in staat waren om een vordering in te stellen. Daarmee is denkbaar dat de subjectieve verjaringstermijn ervoor kan zorgen dat een schuldenaar sneller op de hoogte raakt van mogelijke claims dan wanneer geen subjectieve verjaringstermijn zou gelden.

Met deze algemene beschouwing is nog niet gezegd hoe de wettekst 'de dag, volgende op die waarop de benadeelde zowel met de schade of de opeisbaarheid van de boete als met de daarvoor ansprakelijke persoon bekend is geworden' moet worden geïnterpreteerd. ${ }^{25}$ Als onder die woorden moet worden verstaan dat de rechtszekerheid van de schuldenaar moet worden beschermd, kan die ratio een rol spelen bij de interpretatie en toepassing van dit startmoment. Maar daarvoor is cruciaal dat het subjectieve verjaringsrecht de rechtszekerheid dient. Om te beginnen: hoe kijkt de Hoge Raad tegen de ratio van het subjectieve verjaringsrecht aan?

\subsection{De Hoge Raad over de ratio van subjectief verjaringsrecht}

De Hoge Raad heeft zich niet expliciet uitgelaten over de vraag of de korte verjaringstermijn van art. 3:310 lid 1 BW een (gestandaardiseerde) vorm van rechtsverwerking is, maar heeft wel geoordeeld dat het subjectieve verjaringsrecht in het teken staat van de rechtszekerheid en billijkheid. ${ }^{26}$ De Hoge Raad heeft de billijkheid benadrukt in de context van het startmoment van de korte verjaringstermijn van art. 3:310 lid $1 \mathrm{BW} .{ }^{27}$

24. Vgl. voor een recent voorbeeld met betrekking tot de aansprakelijkheid van een accountantskantoor, Rb. Rotterdam 27 september 2017, ECLI:NL:RBROT:2017:7373, r.o. 2.3-2.22.

25. Art. 3:310 lid $1 \mathrm{BW}$.

26. HR 31 oktober 2003, ECLI:NL:HR:2003:AL8168, NJ 2006/112 m.nt. C.E. du Perron, r.o. 3.4; HR 3 december 2010, ECLI:NL:HR: 2010:BN6241, NJ 2012/196 m.nt. C.E. du Perron, r.o. 3.6; HR 23 oktober 1998, ECLI:NL:HR:1998:ZC2748, NJ 2000/15 m.nt. A.R. Bloembergen (in NJ 2000/16), r.o. 3.3.1.

27. In eerdere jurisprudentie noemde de Hoge Raad de billijkheid nog niet: HR 23 oktober 1998, ECLI:NL:HR:1998:ZC2748, NJ 2000/15 m.nt. A.R. Bloembergen (in NJ 2000/16), r.o. 3.3.1; HR 6 april 2001, ECLI:NL:HR:2001:AB0900, NJ 2002/383 m.nt. H.J. Snijders, r.o. 3.4.2; HR 20 april 2001, ECLI:NL:HR:2001:AB1208, NJ 2002/384 m.nt. H.J. Snijders, r.o. 3.4.2; HR 24 januari 2003, ECLI:NL:HR: 2003:AF0694, NJ 2003/300, r.o. 3.4.2. 
Dat startmoment is volgens de Hoge Raad het moment waarop de schuldeiser daadwerkelijk in staat is om een vordering in te stellen. ${ }^{28}$ Dit oordeel velt de Hoge Raad 'gelet op de strekking' van de korte verjaringstermijn van art. 3:310 lid 1 BW. Het is 'billijk' dat de subjectieve verjaringstermijn pas een aanvang neemt als een schuldeiser daadwerkelijk een vordering kan instellen. Ook overweegt de Hoge Raad dat (onder meer) de billijkheid eraan in de weg staat dat een schuldeiser kan voorkómen dat de korte verjaringstermijn van art. 3:310 lid 1 BW begint te lopen door een redelijkerwijs van hem te verlangen en eenvoudig uitvoerbaar onderzoek naar de identiteit van de schuldenaar niet te verrichten. ${ }^{29}$ Billijkheid noemt de Hoge Raad in het arrest Bosman/G verder als rechtvaardiging voor de regel dat kennis van de juridische beoordeling van feiten over de schade of aansprakelijke persoon bij de schuldeiser irrelevant is voor de aanvang van de korte verjaringstermijn van art. 3:310 lid $1 \mathrm{BW}:{ }^{30}$

'Het zou ook in strijd met de rechtszekerheid zijn wanneer de aanvang van de verjaring afhankelijk zou zijn van het tijdstip waarop de benadeelde juridisch advies inwint. Ook de billijkheid, die naar in het laatstvermelde arrest is overwogen bij de korte verjaringstermijn naast de rechtszekerheid van betekenis is, staat aan het stellen van die eis in de weg. De benadeelde zou immers zonder hinder van deze verjaringstermijn kunnen profiteren van een eerst veel later bekend geworden inzicht met betrekking tot de juridische situatie ten tijde van het ontstaan van de schade, terwijl de aansprakelijke persoon zijn gedrag heeft gericht naar de toen geldende inzichten.' (curs. DB)

Ik lees dit zo, dat de Hoge Raad het onrechtvaardig acht dat een aanspraak nog kan worden afgedwongen als een aansprakelijke persoon zich heeft gedragen conform in het verleden geldende normen en pas later een juridisch inzicht ontstaat dat positief is voor de schuldeiser. Om meer inzicht te krijgen in de ratio van het verjaringsrecht is het interessant om deze rechtsoverweging te vergelijken met een rechtsoverweging uit het latere arrest TMG/Staat: ${ }^{31}$

'Zoals in het arrest Bosman/G is overwogen, zou het stellen van die eis (...) in strijd met de rechtszekerheid zijn wanneer de aanvang van de verjaring afhankelijk is van het tijdstip waarop de benadeelde de juiste juridische beoordeling van de feiten duidelijk is geworden. Voorts zou het, zoals in dat arrest is overwogen, in strijd zijn met de bescher-

28. HR 27 mei 2005, ECLI:NL:HR:2005:AS8455, NJ 2006/114 m.nt. C.E. du Perron, r.o. 3.4. Zie ook Kamerstukken II 2010/11, 32853, nr. 3, p. $2-4(\mathrm{MvT})$.

29. HR 3 december 2010, ECLI:NL:HR:2010:BN6241, NJ 2012/196 m.nt. C.E. du Perron, r.o. 3.6.

30. HR 26 november 2004, ECLI:NL:HR:2004:AR1739, NJ 2006/115 m.nt. C.E. du Perron, r.o. 3.4. Zie ook HR 5 januari 2007, ECLI:NL:HR:2007:AY8771, NJ 2007/320 m.nt. M.R. Mok, r.o. 3.4.2; HR 9 juli 2010, ECLI:NL:HR:2010:BM1688, NJ 2012/194 m.nt. C.E. du Perron, r.o. 3.4.5.

31. HR 4 mei 2018, ECLI:NL:HR:2018:677, NJ 2018/239, r.o. 3.3.3-3.3.4. ming die de korte verjaringstermijn beoogt te bieden, als de benadeelde zonder hinder van die termijn zou kunnen profiteren van een eerst veel later bekend geworden inzicht met betrekking tot de juridische situatie ten tijde van het ontstaan van de schade, terwijl de aansprakelijke persoon zijn gedrag heeft gericht naar de toen geldende inzichten.' (curs. DB)

De rechtsoverwegingen uit beide arresten lijken identiek. De Hoge Raad verwijst in TMG/Staat meermaals naar het arrest Bosman/G. Toch zie ik een opvallend verschil. ${ }^{32}$ In Bosman/ $\mathrm{G}$ benadrukt de Hoge Raad dat de korte verjaringstermijn van art. 3:310 lid $1 \mathrm{BW}$ in het teken staat van de rechtszekerheid en de billijkheid. In TMG/Staat vervangt de Hoge Raad 'billijkheid' met 'de bescherming die de korte verjaringstermijn beoogt te bieden'. Wat die bescherming in het algemeen is, laat de Hoge Raad in TMG/Staat in het midden. Wat de reden voor deze tekstwijziging is, lijkt niet geheel duidelijk. Een mogelijkheid zou zijn dat 'billijkheid' geen duidelijke normatieve richting geeft. In een bepaald opzicht is de billijkheid bij het subjectieve startmoment in het voordeel van de schuldeiser (hij moet op grond van de billijkheid daadwerkelijk in staat zijn om een vordering in te stellen voordat de verjaringstermijn begint te lopen), maar in een ander opzicht komt de billijkheid de schuldenaar ten goede (kennis van de juridische beoordeling van feiten over de schade en aansprakelijke persoon bij een schuldeiser is niet vereist voor de aanvang van de verjaringstermijn). Misschien vormt dit gebrek aan een normatieve richting de reden dat de Hoge Raad in TMG/Staat de billijkheid niet expliciet noemt. Een andere verklaring voor het wijzigen van 'billijkheid' in 'de bescherming die de korte verjaringstermijn beoogt te bieden' is mogelijk dat de Hoge Raad hiermee indirect wil aangeven dat het subjectieve verjaringsrecht de billijkheid als ratio heeft, in plaats van de rechtszekerheid. Hij noemt de rechtszekerheid in TMG/Staat méér dan in Bosman/G als een zelfstandige reden die tegen het vereiste van kennis over de juridische beoordeling pleit. Echter, de gedachte dat het subjectieve verjaringsrecht niet de rechtszekerheid beoogt te beschermen, schuurt met de overweging van de Hoge Raad dat de korte verjaringstermijn bescherming beoogt te bieden tegen de situatie waarin een benadeelde ten koste van de aangesproken partij kan profiteren van een pas veel later bekend geworden juridisch inzicht. Dat is namelijk een rechtszekerheidsargument. De aansprakelijke persoon heeft zijn gedrag afgestemd op de destijds geldende inzichten. Hij moet ervan uit kunnen gaan dat zijn handelen na verloop van tijd niet meer een afdwingbare vordering oplevert, ook als op enig moment zich een gewijzigd inzicht in de juridische situatie heeft voorgedaan dat positief is voor de schuldeiser. Zo

32. De passage 'en zou tot rechtsongelijkheid aanleiding geven waar juridische kennis niet in gelijke mate bij eenieder aanwezig is' uit Bosman/G ontbreekt in TMG/Staat. Dat argument is aan kritiek onderhevig geweest, zie Groeneveld-Tijssens \& Van Schaick 2017a, par. 3. Kampkuiper heeft gesignaleerd dat de Hoge Raad dit argument niet noemt in TMG/Staat, zie L.C. Kampkuiper, Optimalisatie of generalisatie?, in: D.F.H. Stein, V. Tweehuysen \& S.E. Bartels (red.), Verjaring (Onderneming en Recht, deel 120), Deventer: Wolters Kluwer 2020, par. 7.5.1. 


\section{Maandblad}

bezien overweegt de Hoge Raad in TMG/Staat juist dat de korte verjaringstermijn de rechtszekerheid beoogt te beschermen.

De Hoge Raad heeft naar mijn mening dus nog geen afscheid genomen van de gedachte dat het subjectieve verjaringsrecht de rechtszekerheid beoogt te beschermen. Zou dat anders zijn, dan ligt het voor de hand dat de Hoge Raad dat expliciet zou hebben overwogen, zeker gelet op zijn rechtspraak waarin hij (ook) de rechtszekerheid juist benadrukt. ${ }^{33}$ Als de korte verjaringstermijn van art. 3:310 lid $1 \mathrm{BW}$ alleen de billijkheid zou dienen, dan zou betoogd kunnen worden dat het subjectieve verjaringsrecht in de richting van de rechtsverwerkingsgedachte verschuift. Sommigen zien in de 'billijkheid' mogelijk een indirecte en voorzichtige verwijzing naar de rechtsverwerkingsgedachte. ${ }^{34}$ Wordt die rechtsverwerkingsgedachte ondersteund door de parlementaire geschiedenis?

\subsection{Wetsgeschiedenis bevestigt de rechtszekerheidsratio}

Naar mijn mening heeft de wetgever beoogd dat het subjectieve verjaringsrecht rechtszekerheid moet bieden. In het Nieuw BW zijn verjaringstermijnen aanzienlijk verkort. De reden hiervoor was niet dat de wetgever daarmee een gestandaardiseerde vorm van rechtsverwerking wilde introduceren (althans ik vind daar geen expliciete aanwijzingen voor), ${ }^{35}$ maar dat de destijds geldende termijnen te lang waren. Uit een vergelijking met bepaalde landen bleek dat de destijds geldende termijnen relatief lang waren. ${ }^{36}$

De voorgenomen drastische verkorting van verjaringstermijnen stuitte echter op bedenkingen. De wetgever vroeg zich af of in sommige situaties zich ongewenste uitkomsten zouden kunnen voordoen als de schuldeiser 'onbekend is met het ontstaan van de vordering of de persoon van de schuldenaar' (zie het citaat hierna). Om die reden werd het noodzakelijk geacht om een subjectief startmoment te kiezen voor de aanvang van de korte verjaringstermijn van art. 3:310 lid $1 \mathrm{BW}$, zodat deze niet begint te lopen voordat de vordering is ontstaan en voordat de schuldeiser voldoende kennis heeft over het ontstaan van de vordering en de identiteit van de schuldenaar:

33. HR 23 oktober 1998, ECLI:NL:HR:1998:ZC2748, NJ 2000/15 m.nt. A.R. Bloembergen (in NJ 2000/16), r.o. 3.3.1; HR 3 december 2010, ECLI:NL:HR:2010:BN6241, NJ 2012/196 m.nt. C.E. du Perron, r.o. 3.6; HR 31 oktober 2003, ECLI:NL:HR:2003:AL8168, NJ 2006/112 m.nt. C.E. du Perron, r.o. 3.4. Vgl. ook (mogelijk) voor bevrijdende verjaring in het algemeen HR 28 april 2000, ECLI:NL:HR:2000:AA5635, NJ 2000/430 m.nt. A.R. Bloembergen, r.o. 3.3.2.

34. Zie Smeehuijzen 2008, par. 21.2.1.

35. Dat volgt in ieder geval niet uit een passage in de wetsgeschiedenis waarin wordt genoemd dat rechtsverwerking zich (al dan niet snel) voor kan doen voordat een lange verjaringstermijn voltooid raakt; dat is meer een feitelijke observatie. Zie Parl. Gesch. Boek 3, p. 918-920 (eindverslag). Vgl. over een beroep op rechtsverwerking wanneer het verjaringsrecht geen soelaas biedt, Kamerstukken II 2003/04, 26824, nr. 10 (brief minister), p. 2.

36. Parl. Gesch. Boek 3, p. 923 (TM). Vgl. ook Parl. Gesch. Boek 3 (Inv. 3, 5 en 6), p. 1407-1414 (MvT); Kamerstukken I 2002/03, 26824, nr. 105, p. $17-18(\mathrm{NMvA})$.
'Anderzijds bestaat echter tegen een drastische bekorting van de termijn voor alle gevallen van extinctieve verjaring bezwaren. Vooreerst is een aantal gevallen aan te wijzen waar een bekorting tot minder wenselijke resultaten zou leiden. (...) Het kan bovendien gebeuren dat de gerechtigde pas na lange tijd van zijn rechten kennis krijgt. (...) Voor de belangrijke groepen van rechtsvorderingen van de artikelen 3.11.11-13aa geldt de boven aangegeven termijn van vijf jaren, die ten opzichte van het huidige recht een aanzienlijke bekorting betekent zonder nochtans voor de praktijk al te knellend te worden. (...) Ten slotte verdient nog aandacht dat artikel 3.11.11 - anders dan de artikelen 3.11.12a, 13 [art. 3:310 BW; DB] en 13aa-geen rekening houdt met de mogelijkheid dat de schuldeiser onbekend is met het ontstaan van de vordering of de persoon van de schuldenaar.' 37 (curs. DB, m.u.v. 'alle')

Het subjectieve startmoment vormt dus een tegenwicht tegen de verkorting (en daarmee een al te snelle voltooiing) van verjaringstermijnen. In het licht van de hierboven genoemde wetsgeschiedenis over het subjectieve startmoment - waaruit de bedoeling van de wetgever blijkt - en de bewoordingen van art. 3:310 lid 1 BW (bekendheid met de 'schade' en 'de daarvoor aansprakelijke persoon'; curs. DB) kan de korte termijn van art. 3:310 lid $1 \mathrm{BW}$ naar mijn mening pas een aanvang nemen zodra de schuldeiser bekend is met de feiten die de grondslag vormen van de aansprakelijkheid van de schuldenaar.

Maar uit de wetsgeschiedenis volgt óók dat de wetgever met de introductie van een subjectief startmoment geen afstand heeft willen nemen van de rechtszekerheidsratio. Integendeel, hij onderstreept die ratio juist, en in dat verband ook de eis van een snel rechtsverkeer, die eveneens bijdraagt aan de rechtszekerheid van schuldenaren doordat schuldenaren mogelijk eerder op de hoogte raken van claims (zie par. 2-3.1): ${ }^{38}$

'Gekozen is thans voor een oplossing waarin een verjaringstermijn van vijfjaren geldt (...) Enerzijds verdient een bekorting van de termijnen van extinctieve verjaring in beginsel aanbeveling. De mogelijkheid nog aangesproken te kunnen worden dwingt de schuldenaar zijn bewijsmateriaal (kwitanties, girostrookjes, bankafrekeningen, bewijsstukken van een eventuele wanprestatie of ontbinding enz.) te bewaren. Dit brengt kosten mee, die in de sfeer van bedrijf en beroep soms aanzienlijk kunnen oplopen. Ook kan het zijn dat de schuldenaar door het verstrijken van de tijd in bewijsnood rakt, omdat getuigen onvindbaar geworden zijn, hij stukken die derden onder zich hadden, niet meer kan opvragen, of ook omdat hij niet meer de mogelijkheid heeft tot nader onderzoek van hetgeen is voorgevallen.

37. Parl. Gesch. Boek 3 (Inv. 3, 5 en 6), p. 1407-1414 (MvT). Zie ook de vergelijkende opmerkingen over de vordering uit hoofde van onverschuldigde betaling en de schadevergoedingsvordering: Parl. Gesch. Boek 3, p. $922(\mathrm{NvW})$.

38. Parl. Gesch. Boek 3 (Inv. 3, 5 en 6), p. 1407-1414 (MvT). 


\begin{abstract}
Bekorting van de verjaringstermijn stemt ook overeen met de eis van een vlot verlopend rechtsverkeer, waarin schuldeisers hun vorderingen binnen redelijke tijd moeten instellen, zulks mede met het oog op de belangen van de schuldenaar en de rechtszekerheid. Heeft de schuldeiser meer tijd nodig dan kan hij de verjaring stuiten, wat volgens artikel 3.11.17 mogelijk is bij een enkele brief en waardoor de schuldenaar gewaarschuwd wordt, zodat hij zijn bewijsmateriaal e.d. kan vasthouden. Deze overwegingen hebben reeds geleid tot de verkorting van de verjaringstermijn voor de gevallen van de artikelen 3.11.12a en 3.11.13.' (curs. DB)
\end{abstract}

De schuldenaar zou immers beter kunnen inschatten vanaf welk moment hij bewijsmateriaal niet meer hoeft te 'bewaren' en daarvoor geen 'kosten' meer hoeft te maken als de toepassing van de verjaringstermijn in voorkomende gevallen voor hem voorspelbaar is en schuldeisers geprikkeld worden om hun vorderingen tijdig kenbaar te maken aan de schuldenaar. Als een verjaringstermijn onvoldoende voorspelbaar en duidelijk is, 'dwingt' dat de schuldenaar in feite om zekerheidshalve 'zijn bewijsmateriaal (...) te bewaren'. Als de termijn van vijf jaren voor de schuldeiser te kort is, kan hij de verjaring met een schriftelijke verklaring 'stuiten', waarmee de rechtszekerheid van de schuldenaar wordt gewaarborgd (ook richting de toekomst, zie art. 3:319 BW). Doordat denkbaar is dat de korte verjaringstermijn van art. 3:310 lid $1 \mathrm{BW}$ schuldeisers stimuleert die mededeling 'binnen redelijke tijd' te doen, wordt de rechtszekerheid van de schuldenaar vergroot (zie nader par. 2-3.1). Jaren later benadrukte de minister in het kader van de introductie van art. 3:310 lid $5 \mathrm{BW}$ - enkel een subjectieve verjaringstermijn bij letsel- of overlijdensschade ook expliciet het belang van de voorspelbaarheid van verjaringsregels: ${ }^{39}$

'Daar komt bij dat bij verjaringsregels de rechtszekerheid van grote betekenis is, en dat voor betrokken partijen de behoefte aan duidelijke en voorspelbare regels groot is.'

Deze rechtszekerheidsratio kan niettemin botsen met de bedoeling van de wetgever dat een subjectieve verjaringstermijn niet kan beginnen te lopen voordat de vordering is ontstaan. Dat komt ook terug in de rechtspraak van de Hoge Raad. Ik doel op de arresten X\&ASR/Achmea en Achmea/ Vivat. ${ }^{40}$ Daarin stond (onder meer) de vraag centraal wat het startmoment is van de subjectieve verjaringstermijn van art. 3:310 lid $1 \mathrm{BW}$ voor een regresvordering. ${ }^{41}$ De Hoge Raad overwoog dat het startmoment niet eerder kon zijn dan het moment waarop de regresvordering is ontstaan en opeisbaar is geworden, omdat een schuldeiser pas vanaf dat moment daad-

39. Kamerstukken I 2002/03, 26824, nr. 105, p. 14 (NMvA).

40. HR 6 april 2012, ECLI:NL:HR:2012:BU3784, NJ 2016/196 m.nt. C.E. du Perron; HR 15 mei 2020, ECLI:NL:HR:2020:889.

41. Zie hierover uitgebreid Smeehuijzen 2008, par. 21.2.4.3; J.L. Smeehuijzen, De vijfjaarstermijn van art. 3:310 BW bij (i) de fout van een adviseur, (ii) regres bij hoofdelijkheid, (iii) toekomstige schade en (iv) onrechtmatige strafvervolging, NTBR 2011/10; A.C. van Schaick, Het glibberige pad van de verjaring van de regresvordering, NTBR 2012/55. werkelijk in staat is om de vordering in te stellen. ${ }^{42}$ Volgens de Hoge Raad ontstaat de regresvordering pas op het moment dat een hoofdelijke schuldenaar meer dan zijn aandeel aan de schuldeiser heeft betaald. Ik lees de arresten van de Hoge Raad zo dat een vroeger aanvangsmoment van de korte verjaringstermijn tot ongewenste uitkomsten zou leiden. Met andere woorden: een regresvordering zou dan te snel kunnen verjaren, omdat de subjectieve verjaringstermijn in dat geval zou kunnen aanvangen voordat een regresnemer zijn nog niet bestaande vordering kan instellen. In de arresten van de Hoge Raad lees ik dus een bevestiging van de bedoeling van de wetgever dat de korte verjaringstermijn van art. 3:310 lid $1 \mathrm{BW}$ niet te snel voltooid mag raken door een gewenste verkorting van de termijn (zie de hierboven weergegeven passages uit de wetsgeschiedenis).

Het resultaat van deze rechtspraak voor regresvorderingen is veelal een objectief startmoment: het moment waarop een hoofdelijke schuldenaar meer dan zijn aandeel betaalt aan de schuldeiser. ${ }^{43}$ Deze uitkomst staat in een bepaald opzicht op gespannen voet met de rechtszekerheidsratio van art. 3:310 lid $1 \mathrm{BW}$, zoals die blijkt uit de hiervoor angehaalde wetsgeschiedenis. Het is namelijk moeilijk voor een regresschuldenaar om in te schatten wanneer een regresnemer (meer dan zijn aandeel) heeft betaald aan de schuldeiser. Dat neemt niet weg dat ook de wetgever, gelet op de hierboven weergegeven passages uit de wetsgeschiedenis, het onwenselijk acht dat deze verjaringstermijn al een aanvang zou kunnen nemen voordat de vordering is ontstaan.

Ik meen dat de oorzaak van het hier gesignaleerde rechtszekerheidsprobleem voor de regresschuldenaar is gelegen in (1) de bedoeling van de wetgever dat de korte verjaringstermijn van art. 3:310 lid $1 \mathrm{BW}$ pas een aanvang kan nemen als de vordering is ontstaan, in samenhang met (2) de regel dat een regresvordering pas ontstaat op het moment van betaling door een regresnemer aan de schuldeiser. Van Schaick heeft beschreven dat in Duitsland geldt dat een regresvordering al ontstaat op het moment dat de hoofdelijke aansprakelijkheid ontstaat. ${ }^{44}$ Wanneer die regel ook in Nederland zou gelden, zou het rechtszekerheidsprobleem voor een deel kunnen worden weggenomen. Als de regresnemer op het moment van het ontstaan van de hoofdelijke aansprakelijkheid (of later) bekend raakt met de feiten die de grondslag vormen voor zijn hoofdelijke aansprakelijkheid tegenover de schuldeiser, en hij (daarna) óók kennis heeft van de feiten die de grondslag vormen van de interne draagplicht van een andere hoofdelijke schuldenaar (de regresschuldenaar), dan zou voor de regresvordering de korte verjaringstermijn van art. 3:310 lid $1 \mathrm{BW}$ op dat moment een aanvang nemen. ${ }^{45}$ Deze regel is beter voor-

42. HR 15 mei 2020, ECLI:NL:HR:2020:889, r.o. 3.6.2.

43. Zie in kritische zin W.H. van Boom, Het ontstaansmoment en de verjaring van de regresvordering, AA 2013, afl. 1, p. 41-43.

44. Van Schaick 2012, par. 7. Zie over het ontstaansmoment van de regresvordering ook Van Boom 2013, p. 39-41.

45. Vgl. in min of meer soortgelijke zin Van Schaick 2012, par. 8. 


\section{Maandblad}

spelbaar voor de regresschuldenaar, ${ }^{46}$ omdat het valt te verwachten dat hij in voorkomende gevallen een inschatting kan maken vanaf welk moment de regresnemer - zijn medehoofdelijke schuldenaar - de benodigde kennis had. ${ }^{47}$ In deze opvatting wordt aangenomen dat schade van de regresnemer in de zin van art. 3:310 lid $1 \mathrm{BW}$ al bij het ontstaan van de hoofdelijke aansprakelijkheid is ontstaan (hij is immers op dat moment hoofdelijk aansprakelijk voor de gehele schade van de schuldeiser). ${ }^{48}$ In de verhouding tussen hoofdelijke schuldenaren gaat het vervolgens slechts om de verdeling van de vergoeding van die schade onder hoofdelijke schuldenaren. De regresnemer zou zijn rechten tegenover een regresschuldenaar dan kunnen veiligstellen door tijdig een stuitingsverklaring uit te brengen of een vordering in te stellen tegen de regresschuldenaar, waarin deze voorwaardelijk kan worden veroordeeld bij te dragen (al dan niet in een vrijwaringsprocedure). ${ }^{49}$ Duidelijk is evenwel dat dit alles geen geldend recht is.

Bij latere wijzigingen van het verjaringsrecht heeft de wetgever nog benadrukt dat enige objectivering van het subjectieve startmoment noodzakelijk zal zijn, hoewel daarbij (in specifieke contexten) wel rekening kan en moet worden gehouden met omstandigheden met betrekking tot de persoon van de benadeelde. ${ }^{50}$ Dat laatste benadrukt de wetgever met verwijzing naar jurisprudentie van de Hoge Raad. De minister heeft op verschillende momenten benadrukt dat het subjectieve verjaringsrecht (ook) in het teken staat van de rechtszekerheid. ${ }^{51}$

Samengevat: uit de wetsgeschiedenis volgt dat het subjectieve verjaringsrecht (ook) de rechtszekerheid beoogt te dienen,

46. Vgl. over de belangen van de regresschuldenaar Van Schaick 2012, par. 8.

47. Denk bijv. aan hoofdelijke aansprakelijkheid in groepsverband. Zie art. 6:166 BW.

48. Zo bezien hoeft deze oplossing niet op gespannen voet te staan met de overweging van de Hoge Raad dat het ontstaan van schade vereist is voor de aanvang van de korte verjaringstermijn van art. 3:310 lid $1 \mathrm{BW}$. Zie HR 10 oktober 2003, ECLI:NL:HR:2003:AF9416, NJ 2003/680, r.o. 3.4.1. Vgl. in het kader van verhaalsvorderingen de noot van C.E. du Perron bij HR 3 december 2010, ECLI:NL:HR:2010:BN6241, NJ 2012/196, onder 'Bekendheid met de schade'.

49. Art. 3:296 lid 2 en 3:316-319 BW. Zie in min of meer soortgelijke zin Van Schaick 2012, par. 5.

50. Zie in het kader van art. 3:310 lid 5 BW Kamerstukken II 1999/2000, 26824, nr. 3, p. 4 (MvT); Kamerstukken II 1999/2000, 26824, nr. 5, p. 7-8 (NnavV); Kamerstukken I 2001/02, 26824, nr. 128, p. 8-9 (MvA). Later heeft de minister eerdere stellingen enigszins genuanceerd, zie Kamerstukken I 2002/03, 26824, nr. 105, p. 14-15 (NMvA). De wetgever heeft uiteindelijk de subjectiviteit van het startmoment van art. 3:310 lid 5 BW benadrukt door 'dan wel redelijkerwijs bekend had kunnen zijn' (wat was geïntroduceerd naar aanleiding van een amendement, zie Kamerstukken II 2000/01, 26824, nr. 9, p. 1 (amendement)) in te trekken. Zie Kamerstukken II 2003/04, 29414, nr. 3, p. 32-33 (MvT).

51. Zie over schade van minderjarigen Kamerstukken II 1999/2000, 26824, nr. 5, p. 6 (NnavV) (bij amendement is hierop echter teruggekomen, zie Kamerstukken II 2000/01, 26824, nr. 8, p. 1 (amendement)). Vgl. verder Kamerstukken II 2010/11, 32853, nr. 3, p. 4 (MvT); Kamerstukken I 2001/02, 26824, nr. 128, p. 10 (MvA). Vgl. ook Kamerstukken II 1988/89, 21202, nr. 3, p. 59, onder 3 (MvT); Kamerstukken II 1991/92, 22599 , nr. 3, p. 2, onder 3 (MvT); over art. 3:306 BW, zie Kamerstukken II 1992/93, 22599, nr. 5, p. 2, onder 4 (MvA); over rechtszekerheid en art. 3:307 BW, zie Parl. Gesch. Boek 3 (Inv. 3, 5 en 6), p. 1407-1414 (MvT). waarbij het subjectieve startmoment een waarborg vormt tegen een al te snel voltooide verjaringstermijn. Die rechtszekerheidsratio is in de wetsgeschiedenis benadrukt. Bovendien bevestigen naar mijn mening de volgende aspecten van het subjectieve verjaringsrecht deze ratio.

\section{Aspecten van subjectief verjaringsrecht bevestigen rechtszekerheidsratio}

\subsection{Aspect 1: geen onevenredig nadeel of geschonden gerechtvaardigd vertrouwen vereist}

In theorie is het denkbaar dat de korte verjaringstermijn van art. 3:310 lid $1 \mathrm{BW}$ afloopt zonder dat een daarna ingestelde vordering tot enig onredelijk feitelijk nadeel of geschonden gerechtvaardigd vertrouwen voor de schuldenaar of een derde leidt. Waarom zou een beroep op de korte verjaringstermijn van art. 3:310 lid $1 \mathrm{BW}$ in dat geval toch kunnen slagen, als zijn ratio slechts bestaat uit het voorkomen van nadeel of geschonden vertrouwen door verwijtbaar stilzitten (een vorm van rechtsverwerking)? Een reactie zou kunnen zijn dat het subjectieve verjaringsrecht dergelijk nadeel of geschonden vertrouwen veronderstelt zodra de subjectieve verjaringstermijn is verlopen. ${ }^{52}$ Maar wat is de rechtvaardiging van die abstractie? Dat een beroep op de korte verjaringstermijn toch kan slagen, volgt naar mijn mening uit het feit dat de korte verjaringstermijn van art. 3:310 lid $1 \mathrm{BW}$ is bedoeld om rechtszekerheid te bieden. Die rechtszekerheid gaat voor een groot deel verloren als onevenredig nadeel of geschonden gerechtvaardigd vertrouwen als gevolg van verwijtbaar stilzitten door de schuldeiser in het concrete geval vereist is, omdat het verjaringsrecht daarmee minder voorspelbaar wordt. ${ }^{53}$ Tegelijkertijd zouden die omstandigheden wel relevant zijn voor een algemene billijkheidsafweging.

\subsection{Aspect 2: kennis van de juridische beoordeling van feiten over de schade en aansprakelijke persoon is voor het subjectieve startmoment niet van belang}

Voor de beoordeling van het startmoment van de korte verjaringstermijn van art. 3:310 lid $1 \mathrm{BW}$ is volgens vaste jurisprudentie van de Hoge Raad niet relevant wanneer de schuldeiser bekend is geworden met de juridische beoordeling van feiten over de schade en de aansprakelijke persoon. ${ }^{54}$ Deze rechtsregel vergroot de voorspelbaarheid van het subjectieve verjaringsrecht. Dat een schuldeiser verwijtbaar zou stilzitten wanneer hij een vordering te laat instelt omdat hij niet op de hoogte was van de juridische beoordeling van feiten over de schade of de aansprakelijke persoon gaat mij in algemene zin ook te ver. ${ }^{55}$ De rechtsverwerkingsgedachte verklaart deze regel naar mijn mening dus niet goed (in ieder geval niet in alle

52. J.J. Valk, Het toepassingsbereik van de klachtplicht, MvV 2020, afl. 2, p. 46.

53. Vgl. over het verschil tussen de klachtplicht en verjaring de conclusie van A-G Wissink bij HR 8 februari 2013, ECLI:NL:HR:2013:BY4600, NJ 2014/497 m.nt. Jac. Hijma, punt. 2.7.3 en 3.7.3.

54. Zie bijv. HR 4 mei 2018, ECLI:NL:HR:2018:677, NJ 2018/239, r.o. 3.3.3.

55. Vgl. over rechtsdwaling en verjaring Smeehuijzen 2008, par. 9.2, 21.2.2.4. 


\section{Maandblad}

gevallen). Zonder deze regel zou juist de rechtszekerheid aan kracht inboeten, ${ }^{56}$ omdat dan slechter kan worden voorspeld wanneer de schuldeiser de nodige kennis had. In dit verband is relevant dat de Hoge Raad zeer recent zijn jurisprudentie heeft bijgesteld (of verduidelijkt) in die zin dat hij heeft geoordeeld dat juridische kennis over de vraag of een prestatie deugdelijk is geweest relevant kan zijn voor de aanvang van de korte verjaringstermijn van art. 3:310 lid $1 \mathrm{BW} .{ }^{57}$ Daarmee is het aanvangsmoment slechter voorspelbaar (geworden). De Hoge Raad overweegt in r.o. 3.3.3 zelfs dat onder omstandigheden de vereiste duidelijkheid pas na een rechterlijk oordeel aanwezig kan zijn. Het gaat het bestek van dit artikel te buiten om uitgebreid op dit arrest in te gaan en daarom volsta ik hier met een tweetal kritische vragen. Ten eerste, de overweging dat de vereiste zekerheid onder omstandigheden pas na een rechterlijk oordeel aanwezig kan zijn, roept de vraag op of bedoeld wordt een rechterlijk oordeel in de verhouding tussen de eiser en een derde partij (in het geval van deze casus: de fiscus) - waardoor de eiser na dat rechterlijk oordeel zeker weet dat hij in de verhouding met die derde niet krijgt wat hij verwachtte - of dat de Hoge Raad zelfs bedoelt dat de eiser soms pas voldoende kennis heeft na de uitkomst van de procedure tegen diegene die de prestatie heeft geleverd (in casu: de belastingadviseur). Hoewel de Hoge Raad het erg breed formuleert en strikt genomen eiser mogelijk pas na een procedure tegen de prestant zelf zekerheid heeft over de vraag of aan de prestatie een gebrek kleeft, ga ik met enige voorzichtigheid - mede nu het arrest is gewezen in de context van een beroepsaansprakelijkheidsprocedure en daar dit soort vragen vaak spelen - uit van het eerste en dat de Hoge Raad met genoemde overweging doelt op dergelijke separate rechterlijke oordelen. En ten tweede, wat is de rechtvaardiging van het onderscheid tussen kennis van de juridische beoordeling van feiten over de schade en aansprakelijke persoon enerzijds en kennis van de juridische beoordeling van feiten over de deugdelijkheid van een prestatie anderzijds? ${ }^{58} \mathrm{Als}$ een benadeelde haar vordering niet heeft ingesteld omdat zij geen wetenschap had van andere juridische kennis dan die over de deugdelijkheid van een prestatie,

56. Over de rechtvaardiging van rechtsdwaling bij de toepassing van het subjectieve verjaringsrecht is een kritisch tweeluik verschenen. Zie Groeneveld-Tijssens \& Van Schaick 2017a; N.E. Groeneveld-Tijssens \& A.C. van Schaick, Een tweeluik over bevrijdende verjaring en rechtsdwaling. Deel II: de advocaat en de subsidiaire vordering, NTBR 2017/15 (hierna: Groeneveld-Tijssens \& Van Schaick 2017b). Zie ook Smeehuijzen 2008 par. 9.2, 21.2.2.4; noot van C.E. du Perron bij HR 26 november 2004 , ECLI:NL:HR:2004:AR1739, NJ 2006/115; Kampkuiper 2020, par. 7.1-7.6.

57. HR 9 oktober 2020, ECLI:NL:HR:2020:1603, r.o. 3.3.3. De Hoge Raad overweegt: 'Deze juridische beoordeling ziet niet op de kennis en het inzicht die nodig zijn om de deugdelijkheid van een geleverde prestatie te beoordelen, anders dan uit eerdere uitspraken van de Hoge Raad zou kunnen worden afgeleid' (r.o. 3.3.3).

58. A-G Valk formuleert gevallen waarin een algehele onmogelijkheid om een beroep te doen op rechtsdwaling niet gerechtvaardigd is. Zie de conclusie van A-G Valk bij HR 9 oktober 2020, ECLI:NL:HR:2020:1603, punt 3.3-3.12. Hij onderscheidt de volgende gevallen: 'Er zijn namelijk ook gevallen waarin, in verband met de tussen partijen bestaande rechtsverhouding, de onzekerheid omtrent de juiste juridische beoordeling van de feiten partijen niet in gelijke mate aangaat, maar vooral een van hen' (punt 3.5). waarom kan dat gebrek aan kennis dan nooit (in geen enkel geval) relevant zijn voor het startmoment van de subjectieve verjaringstermijn? ${ }^{59}$

\subsection{Aspect 3: derogerende werking van de redelijkheid en billijkheid als correctie op de rechtszekerheid}

Dat het subjectieve verjaringsrecht (ook) de rechtszekerheid dient, verklaart de rol van de derogerende werking van de redelijkheid en billijkheid bij de korte termijn van art. 3:310 lid 1 BW. De Hoge Raad heeft de derogerende werking van de redelijkheid en billijkheid ook bij het subjectieve verjaringsrecht toegepast. ${ }^{60}$ In de (geparafraseerde) woorden van Snijders: art. 6:2 lid 2 BW stelt de rechter in staat om een beroep op een verjaringstermijn en de rechtszekerheid die deze termijn biedt uit te sluiten als een beroep daarop naar maatstaven van redelijkheid en billijkheid onaanvaardbaar is. ${ }^{61}$ Art. 6:2 lid $2 \mathrm{BW}$ is geen onderdeel van het (subjectieve) verjaringsrecht, maar geeft een rechter ruimte om op basis van alle relevante omstandigheden van het geval in een concrete zaak af te wijken van een verjaringsregel. Illustratief voor het feit dat het subjectieve verjaringsrecht niet zijn grondslag vindt in de redelijkheid en billijkheid - en in die zin dus ook niet een vorm van rechtsverwerking is - is dat er zich omstandigheden kunnen voordoen nadat de subjectieve verjaringstermijn is aangevangen waardoor niet langer van een schuldeiser redelijkerwijs mag worden verwacht dat hij zijn vordering instelt, maar de vordering toch in beginsel verjaart. Denk aan een geval van misbruik waarin drie jaar nadat het misbruik en de psychische overmacht zijn opgehouden iemand weer in de invloedsfeer van de dader raakt. Is het dan redelijk of billijk dat een rechtsvordering twee jaar later wordt ontzegd door een voltooide verjaringstermijn? Dat kan serieus worden betwijfeld. ${ }^{62}$ De korte verjaringstermijn van art. 3:310 BW vereist een startmoment, maar het is denkbaar dat de redelijkheid of billijkheid van de korte verjaringstermijn wordt ondergraven door feiten die zich na het startmoment hebben afgespeeld. De korte verjaringstermijn van art. 3:310 lid $1 \mathrm{BW}$ hoeft dus niet noodzakelijkerwijs redelijke en billijke gevolgen te hebben.

59. Vgl. bijvoorbeeld in kritische zin over de onmogelijkheid van een beroep op objectieve rechtsdwaling (in het licht van het EVRM), GroeneveldTijssens \& Van Schaick 2017a, par. 5, 6 en 10.

60. Zie HR 23 november 2018, ECLI:NL:HR:2018:2047, NJ 2019/246 m.nt. J.B.M. Vranken, r.o. 3.3.3, waarin de Hoge Raad benadrukt dat het feit dat de korte verjaringstermijn van art. 3:310 lid $1 \mathrm{BW}$ 'mede' de billijkheid dient, niet een beroep op art. 6:2 lid 2 BW in de weg hoeft te staan. Zie over de rol van de billijkheid bij verjaringsrecht Bouma \& Kroeze 1999, p. 37-41.

61. Zie de noot van H.J. Snijders bij HR 20 april 2001, ECLI:NL:HR: 2001:AB1208, NJ 2002/384, onder 7.

62. Ik meen dat een beroep op art. 6:2 lid 2 BW hier kansrijk moet zijn voor de schuldeiser. Art. 6:2 lid 2 BW is echter geen onderdeel van het verjaringsrecht. Vgl. de casuspositie in HR 23 oktober 1998, ECLI:NL:HR: 1998:ZC2748, NJ 2000/15 m.nt. A.R. Bloembergen (in NJ 2000/16), r.o. 3.3.1-3.3.2. Zie over de rol van de billijkheid bij verjaringsrecht Bouma \& Kroeze 1999, p. 37-41. 


\subsection{Aspect 4: geen absolute zekerheid vereist}

Een laatste aspect van het subjectieve verjaringsrecht dat de rechtszekerheidsratio bevestigt, is dat geen absolute of exacte zekerheid bij de schuldeiser vereist is over de identiteit van de aansprakelijke persoon en hoe de schade van de schuldeiser is ontstaan. ${ }^{63}$ Verder begint de verjaringstermijn voor 'toekomstige schadeposten die als afzonderlijke elementen van dezelfde doorlopende schade moeten worden gezien, en voorzienbaar zijn' op hetzelfde moment te lopen als de termijn voor de aanvankelijk ingetreden (doorlopende) schade. ${ }^{64}$ Deze regels vergroten de rechtszekerheid van de schuldenaar. Schuldenaren hoeven na voltooiing van de korte verjaringstermijn geen rekening te houden met afdwingbare schadevergoedingsvorderingen voor schadeposten die al voorzienbaar waren bij het ontstaan van de aanvankelijk ingetreden doorlopende schade en als elementen van die schade moeten worden aangemerkt. $\mathrm{Zij}$ hoeven ook niet na te gaan wanneer er sprake is van absolute subjectieve zekerheid bij een schuldeiser (wat heel moeilijk kan blijken uit objectieve omstandigheden), maar moeten een inschatting maken - zoals de Hoge Raad het heeft uitgedrukt - van het moment waarop voor de schuldeiser 'voldoende zekerheid' bestond 'dat de schade is veroorzaakt door tekortschietend of foutief handelen van de betrokken persoon'. ${ }^{65}$ Het is echter wel de vraag hoe de invulling van dit criterium door de Hoge Raad zich verhoudt tot de rechtszekerheidsratio en de specifieke bedoeling van de wetgever bij het startmoment van de korte verjaringstermijn van art. 3:310 lid 1 BW (zie ook par. 2-3). Om dit criterium draaide het in het recente arrest Mispelhoef/Staat. ${ }^{66}$

\section{De koers van de Hoge Raad in Mispelhoef/Staat}

In Mispelhoef/Staat moest de Hoge Raad oordelen over het aanvangsmoment van de korte verjaringstermijn van art. 3:310 lid $1 \mathrm{BW}$ in een geval waarin voor de eisende partij (Mispelhoef) enige onzekerheid bestond over de oorzaak van haar schade. Pas na enige tijd en onderzoek werd voor Mispelhoef duidelijk dat Rijkswaterstaat haar schade had veroorzaakt. A-G Keus sloot zich aan bij het hof en overwoog dat op het moment dat Mispelhoef kennis had van de mogelijkheid dat de handelingen van Rijkswaterstaat haar schade hadden veroorzaakt de vereiste 'voldoende zekerheid' bij Mispelhoef

63. Zie over de vereiste mate van feitenkennis en de onderzoeksplicht van een schuldeiser HR 4 mei 2018, ECLI:NL:HR:2018:677, NJ 2018/239, r.o. 3.3.2; HR 31 maart 2017, ECLI:NL:HR:2017:552, NJ 2017/165, r.o. 3.3.2; HR 3 december 2010, ECLI:NL:HR:2010:BN6241, NJ 2012/196 m.nt. C.E. du Perron, r.o. 3.6; HR 2 december 2011, ECLI:NL:HR:2011:BR5216, NJ 2012/197 m.nt. T.F.E. Tjong Tjin Tai, r.o. 3.5.2; HR 10 september 2010, ECLI:NL:HR:2010:BM7041, NJ 2012/195 m.nt. C.E. du Perron, r.o. 3.5; HR 9 oktober 2009, ECLI:NL:HR:2009:BJ4850, NJ 2012/193 m.nt. C.E. du Perron, r.o. 3.6; Smeehuijzen 2008, par. 21.2.2.3 en 21.2.2.5; Smeehuijzen 2011, p. 74-86; Asser/Sieburgh 6-II 2017/411.

64. HR 15 mei 2020, ECLI:NL:HR:2020:889, r.o. 3.7

65. Zie HR 4 mei 2018, ECLI:NL:HR:2018:677, NJ 2018/239, r.o. 3.3.2; HR 31 maart 2017, ECLI:NL:HR:2017:552, NJ 2017/165, r.o. 3.3.2.

66. HR 31 maart 2017, ECLI:NL:HR:2017:552, NJ 2017/165, r.o. 3.3.2. Zie ook HR 10 januari 2020, ECLI:NL:HR:2020:20, NJ 2020/122 m.nt. T.F.E. Tjong Tjin Tai, r.o. 3.1-3.2.3 en 3.4.1-3.4.2 (een gedeeltelijk contrair arrest). bestond. ${ }^{67}$ De Hoge Raad zag het anders: 'voldoende zekerheid' moet zo worden opgevat dat de subjectieve verjaringstermijn pas begon te lopen na een door Mispelhoef gelast onderzoek waaruit duidelijk werd dat handelingen van Rijkswaterstaat de oorzaak waren van de schade van Mispelhoef.

In het algemeen lijkt het startmoment dat A-G Keus en het hof kozen meer rechtszekerheid voor de schuldenaar op te leveren. Immers: met die uitkomst kan de schuldenaar in voorkomende gevallen beter inschatten wanneer de verjaringstermijn begint te lopen. Met de manier waarop de Hoge Raad 'voldoende zekerheid' invult, wordt die voorspelling een stuk moeilijker, omdat het startmoment in dat geval meer afhankelijk wordt van andere omstandigheden, zoals de duur en uitkomsten van nader onderzoek. ${ }^{68}$ Ook in gevallen waarin de schuldenaar onbekend is met het feit dat hij de schade heeft veroorzaakt (mogelijk was dat aan de orde in Mispelhoef/ Staat), lijkt de redenering van A-G Keus en het hof vanuit rechtszekerheidsperspectief wenselijker. Het valt te verwachten dat schuldenaren in dergelijke gevallen sneller kennis zullen krijgen van mogelijke claims (door stuitingsbrieven of door het daadwerkelijk instellen van een claim). Daardoor kunnen schuldenaren beter rekening houden met claims bij het bewaren van bewijsmateriaal of andere (economische) beslissingen (zie par. 2 en 3 ).

Dit alles laat onverlet dat men het onredelijk of onbillijk kan vinden dat een korte verjaringstermijn kan beginnen te lopen voordat de schuldeiser 'voldoende zekerheid' heeft in de betekenis die de Hoge Raad in Mispelhoef/Staat aan dit criterium geeft. Ik zie twee mogelijke gronden om het oordeel van de Hoge Raad te rechtvaardigen, ondanks de kanttekeningen die ik hiervoor maakte vanuit het rechtszekerheidsperspectief. Ten eerste, wellicht vereist de billijkheid dat een schuldeiser eerst tijd moet worden gegund om een onderzoek in te stellen voordat de termijn begint te lopen. Een opening voor deze correctie op de rechtszekerheidsratio van de korte verjaringstermijn van art. 3:310 lid $1 \mathrm{BW}$ heeft de Hoge Raad zelf gegeven: hij oordeelde eerder dat de korte verjaringstermijn ook in het teken van de billijkheid staat (zie par. 3.2). ${ }^{69}$ Problematisch vanuit het rechtszekerheidsperspectief is wel dat wat voor de een billijk is, dat voor een ander misschien niet is, en dat een billijkheidsbeoordeling in ieder geval een analyse vergt

67. Concl. A-G Keus bij HR 31 maart 2017, ECLI:NL:HR:2017:552, NJ 2017/165, zie met name punt 2.6.

68. Vgl. over de moeilijkheid van vaststelling van het startmoment de noot van T.F.E. Tjong Tjin Tai bij HR 10 januari 2020, ECLI:NL:HR: 2020:20, NJ 2020/122, onder 3.

69. Vgl. over de rol van de billijkheid de noot van C.E. du Perron bij HR 3 december 2010, ECLI:NL:HR:2010:BN6241, NJ 2012/196, onder 'Inleiding'. 
van alle relevante omstandigheden. ${ }^{70}$ In voorkomende gevallen geldt dit mijns inziens ook voor de vraag wanneer van een schuldeiser redelijkerwijs kon worden verwacht dat hij zijn vordering instelde (de rechtsverwerkingsgedachte). Ten tweede, men zou op grond van de wetsgeschiedenis van de korte verjaringstermijn van art. 3:310 lid $1 \mathrm{BW}$ wellicht kunnen verdedigen dat de verjaringstermijn pas begint te lopen bij 'voldoende zekerheid' in de betekenis die de Hoge Raad daaraan geeft, omdat de wetgever beoogd heeft dat deze termijn pas begint te lopen wanneer de schuldeiser bekend is met het ontstaan van zijn vordering (zie nader par. 3.3). Volledig sluitend lijkt deze tweede redenering overigens niet. Uit de wetsgeschiedenis wordt niet helemaal duidelijk welke mate van bekendheid nodig is.

Kortom: de invulling van het startmoment in het arrest Mispelhoef/Staat kan niet slechts worden verklaard door de rechtszekerheidsratio van het subjectieve verjaringsrecht. Die invulling zou wellicht wel kunnen worden verklaard door een (zeer) welwillende interpretatie van de wetsgeschiedenis of door aan te nemen dat in feite sprake is van een correctie op de rechtszekerheidsratio op grond van de door de Hoge Raad geïntroduceerde billijkheid.

\section{Rechtsverwerking en rechtszekerheid}

Ten slotte, ook door het rechtsverwerkingsleerstuk centraal te stellen wordt duidelijk dat er een verschil bestaat tussen de mate van voorspelbaarheid van subjectief verjaringsrecht en rechtsverwerking.

Naar mijn mening stelt rechtsverwerking een schuldenaar of derde (na overleg) niet goed in staat om zonder (al te veel) onzekerheid of rechterlijke tussenkomst te bepalen of een vordering nog kan worden afgedwongen. ${ }^{71}$ Rechtsverwerking is een toepassing van de derogerende werking van de redelijkheid en billijkheid. ${ }^{72}$ Een schuldeiser kan zijn aanspraak niet te gelde maken als het door zijn eerdere gedragingen naar maatstaven van redelijkheid en billijkheid onaanvaardbaar zou zijn om daarop een beroep te doen. Het gaat dus om een zware en open toets, waarbij de gedragingen van de schuldeiser centraal staan. Rechtsverwerking vereist bovendien onevenredig nadeel, bijvoorbeeld in de vorm van bewijsnood of kosten, of gerechtvaardigd vertrouwen bij de schuldenaar. ${ }^{73}$ Dat

70. Het arrest Mispelhoef/Staat is wat mij betreft illustratief. Ik meen uit de conclusie van A-G Keus op te mogen maken dat hij zijn benadering in overeenstemming acht met de billijkheid. In plaats van de billijkheid als rechtvaardiging van de korte verjaringstermijn te zien, zou ook denkbaar zijn dat de Hoge Raad de billijkheid nadrukkelijker als een correctie hanteert door de billijkheid slechts toe te passen in het kader van art. 6:2 lid 2 BW.

71. Vgl. over rechtszekerheid en rechtsverwerking Smeehuijzen 2008, par. 9.2 .

72. HR 11 november 2016, ECLI:NL:HR:2016:2574, NJ 2017/75 m.nt. P. van Schilfgaarde, r.o. 4.2. Zie over de rechtsgrondslag van rechtsverwerking W.L. Valk, Rechtsverwerking in drievoud (diss. Leiden), Deventer: Kluwer 1993, p. 91-100.

73. Asser/Sieburgh 6-III 2018/426; HR 11 november 2016, ECLI:NL:HR: 2016:2574, NJ 2017/75 m.nt. P. van Schilfgaarde, r.o. 4.2. moet blijken uit bijzondere omstandigheden. Tijdsverloop kan een relevante omstandigheid zijn, maar is in beginsel niet genoeg voor een rechtsverwerkingsoordeel. Toepassing van het leerstuk vraagt dus om een juridische beoordeling van het gedrag van de schuldeiser in het licht van een aantal open normen (redelijkheid en billijkheid, bijzondere omstandigheden, onaanvaardbaarheid, gerechtvaardigd vertrouwen en onevenredig nadeel) en aan de hand van alle (relevante) omstandigheden van het geval binnen een niet-vastomlijnde periode.

Daarmee mist rechtsverwerking een eenvoudig en abstract criterium waarmee een schuldenaar zonder (al te veel) onzekerheid of rechterlijke tussenkomst kan bepalen of een vordering nog kan worden afgedwongen. ${ }^{74}$ Weliswaar moet bij het subjectieve verjaringsrecht worden nagegaan - wat in voorkomende gevallen moeilijk kan zijn - wanneer de schuldeiser daadwerkelijk in staat was een vordering in te stellen, maar de toepassing van dat criterium is in algemene zin meer voorspelbaar dan de toepassing van de voorwaarden die voor rechtsverwerking gelden (zie par. 2-5). Ook valt - naar mijn inschatting - niet te verwachten dat schuldeisers door het rechtsverwerkingsleerstuk worden geprikkeld om schuldenaren spoedig op de hoogte te stellen van mogelijke claims voor schade waarvan schuldenaren zich mogelijk onbewust zijn.

\section{Conclusie}

Met het normatief kader dat ik in dit artikel formuleer, beoog ik een bijdrage te leveren aan het begrip van de normatieve achtergrond van het subjectieve verjaringsrecht. Mijn conclusie is dat de korte verjaringstermijn van art. 3:310 lid 1 BW ook de rechtszekerheid beoogt te dienen. Naar mijn mening is deze korte verjaringstermijn daarom niet geheel hetzelfde als een vorm van rechtsverwerking (in conceptuele zin). Verschillende aspecten van het subjectieve verjaringsrecht bevestigen dat. De wetgever heeft bij de korte verjaringstermijn van art. 3:310 lid $1 \mathrm{BW}$ verder voor een subjectief startmoment gekozen, omdat vorderingen anders te snel zouden kunnen verjaren. De bedoeling van de wetgever bij dat subjectieve startmoment is geweest dat de korte verjaringstermijn pas een aanvang neemt zodra de schuldeiser bekend is met de feiten die de grondslag vormen van de aansprakelijkheid van de schuldenaar. De invulling van het startmoment in rechtspraak van de Hoge Raad, waarbij hij de nadruk legt op alle relevante omstandigheden van het geval, lijkt niet volledig te kunnen worden verklaard door de rechtszekerheidsratio. Ik heb twee argumenten genoemd waarmee men die rechtspraak toch kan rechtvaardigen: de billijkheid als correctiemogelijkheid en/of een (zeer) welwillende lezing van de wetsgeschiedenis. Deze rechtvaardiging neemt niet weg dat door de aanvang van de subjectieve verjaringstermijn (steeds meer) afhankelijk te maken van uiteenlopende omstandigheden, deze termijn voorspelbaarheid verliest en daarmee minder rechtszekerheid biedt.

74. Vgl. over rechtszekerheid en rechtsverwerking Smeehuijzen 2008, par. 9.2 . 